\title{
Citizen science i Danmark: Projekter, litteratur og aktører
}

\section{Identificering af fag- og forskningsbibliotekernes rolle ift. udbredelse og understøttelse af Citizen Science. Det er titlen på et DEFF-projekt som løber til og med udgangen af i år.}

\author{
Anbefalingerne er blevet trykt i en rapport og blevet diskuteret \\ ved en høring på Den Sorte Diamant. \\ Rapporten er udkommet den 16. november med titlen \\ "Citizen science i Danmark: Projekter, litteratur og aktører. \\ REVY bringer her det afsluttende efterskrift med relation til \\ fag-og forskningsbibliotekerne
}

\section{Kapitel 5 Anbefalinger til fag- og forskningsbibliotekerne}

Efterskrift ved Thomas Kaarsted og Kristian Hvidtfelt Nielsen

I dette efterskrift fremsætter vi en række anbefalinger til fag-og forskningsbibliotekerne (herefter bare forskningsbibliotekerne) samt andre aktører eller partnere, som kunne indgå i samarbejder med forskningsbibliotekerne omkring citizen science. Inspirationen er nærværende rapport samt input fra øvrige delprojekter i DEFF-projektet "Identificering af fag-og forskningsbibliotekernes rolle ift. udbredelse og understøttelse af Citizen Science" og aktiviteter, som er udsprunget eller haft tilknytning til projektet, herunder citizen science-symposium, masterclasses, workshops og undervisning.
På den internationale front er forskningsbiblioteker begyndt at interessere sig aktivt og målrettet for citizen science (Ignat \& Ayris, 2020, Ignat et al., 2018). I 2019 etablerede Association of European Research Libraries (LIBER) en Citizen Science Working Group.

Arbejdgruppen har til formål at tage initiativ til og engagere sig i eventuelle forskningsprojekter om citizen science (inden oktober 2021), udarbejde et holdningsdokument om forskningsbibliotekernes rolle som "single citizen science point of contact" (oktober 2012, jf. afslutningen på forrige kapitel) og lave andre former videndeling og værktøjer for forskningsbibliotekerne (Citizen Science Working Group, 2020). i 2020 afholdt European Bureau of Library Information and Documentation Associations (EBLIDA) og LIBER en fælles virtuel workshop om citizen science og FN's Verdensmål.

Internationalt set er det tydeligt, at forskningsbiblioteker er meget forskellige, også når det gælder citizen science. Forskningsbibliotekerne er etableret for at servicere forskningsinstitutioner, som har forskellige målsætninger og arbejdsmetoder. Desuden er der lokale, regionale og nationale forskelle, der gør sig gældende i forhold til forskning, kultur, demografi, politik og økonomi.

Selv inden for det danske forskningsbibliotekslandskab er der store forskelle. Når det gælder anbefalinger til forskningsbiblioteker, er det derfor 
værd at være opmærksom på, at der kan - og bør - være forskelle i prioritering og implementering. Der ligger (næsten) altid et forudgående analysearbejde, som drejer sig om at tilpasse anbefalingerne til den konkrete kontekst.

Vi opstiller anbefalingerne på to niveauer: strategisk og operationelt. På det strategiske niveau kan forskningsbiblioteker, der måtte ønske at arbejde videre med citizen science, selv definere deres egen rolle og eget bidrag i dialog med samarbejdspartnerne og interessenter. På det operationelle niveau er der fokus på konkrete indsatsområder og opmærksomhedspunkter, hvor bibliotekerne potentielt kan få en rolle og give merværdi til hele citizen science-feltet. Det er vigtig at understrege, at anbefalingerne skal ses som inspiration til de forskningsbiblioteker, der har interesse for at engagere sig (yderligere) i citizen science, og at der er et foranstående arbejde i at gøre de valgte anbefalinger relevante for den enkelte organisation. Der er ikke én model, der passer til alle.

\subsection{Strategiske anbefalinger}

Under hensyntagen til forskningsbibliotekernes forskellighed, men også af hensyn til forankringen på det konkrete forskningsbibliotek, er det vigtigt, at hvert enkelt forskningsbibliotek gør sig konkrete strategiske overvejelser. Til dette arbejde vil vi fremsætte følgende anbefalinger:

1. Institutionalisering: Denne anbefaling ligger i forlængelse af rapportens konklusion i kapitel 4. Rapporten har bekræftet, at citizen science primært foregår "nedefra-og-op". Konkrete citizen science-projekter bliver sat i gang af forskere, forskergrupper eller organisationer, men uden en bredere institutionel opbakning. Hvis citizen science i de kommende år skal udvikle et

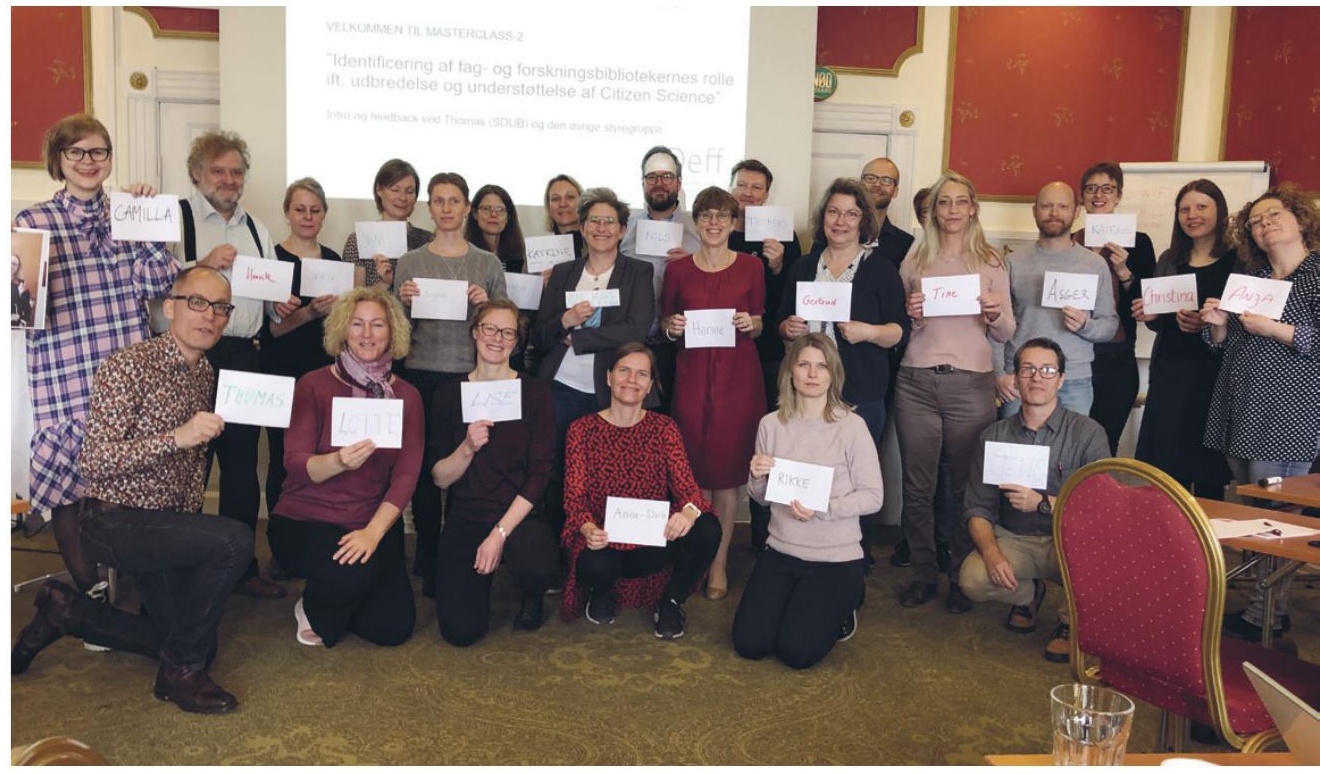

stærkere rodnet, så skal arbejdet og energien fra "de tusind blomster, der blomstrer" kanaliseres ind i mere faste institutionelle rammer, som for eksempel et "single point of contact", nævnt rapportens afsnit 4.3.3. Vi vil her også nævne Broad Engagement in Science, Point of Contact (BESPOC) (Ayris \& Ignat, 2020). BESPOC-modellen har til formål at levere en helhedstænkning omkring forskningspartnerskaber, der har til formål at understøtte Open Science-principper med mange typer af aktører og organisationer og med mange forskellige mål og midler. Her indgår citizen science og forskningsbiblioteker som en del af de mange samarbejdsmuligheder, redskaber og netværk, der kan være med til at fremme åbenhed, deling og samarbejde på forskningsinstitutionerne. Institutionalisering af citizen science - og forskningsinstitutionernes bidrag i forhold til dette - bliver i BESPOC-modellen altså set som del af en større forandringsproces inden for forskningsverden.
2. Prioritering: Rapporten har vist, at der er interesse for at knytte forskningsbibliotekerne til citizen science-initiativer, særligt i forhold til formidling og datahåndtering, men også at der er udfordringer omkring kapacitetsopbygning og prioritering. Det er derfor nærliggende at anbefale en tydelig ledelsesmæssig prioritering af opgave relateret til citizen science for de forskningsbiblioteker, der har interesse for området. Prioriteringen skal kommunikeres tydeligt både internt og eksternt. Flere respondenter i nærværende rapport angiver bibliotekerne som en mulig samarbejdspartner, men her ligger endnu en kommunikationsopgave, for hvordan bliver dette gjort tydeligt for medarbejdere eller potentielle partnere? I den forbindelse kan det være et yderligere opmærksomhedspunkt at reducere kompleksiteten i forskningsbibliotekets arbejdsområder. Hvis et forskningsbibliotek ønsker at prioritere området, skal man samtidigt definerer sin rolle (gerne i dialog med partnere) og være tydelige på forskningsbibliotekets konkrete roller og services i den forbindelse. 


\section{CITIZEN SCIENCE}

3. Netværksdannelse: Nogle forskningsbiblioteker er allerede engageret eller interesseret i citizen science, og området gennemgår i disse år en stærkere organisering. Forskningsbibliotekerne anbefales derfor at deltage i eksisterende arbejdsgrupper, organisationer, netværk eller projektkonsortier, alternativt selv tage initiativ til nye. På denne måde kan forskningsbibliotekerne ikke bare selv få adgang til nyttige forbindelser og ressourcer, men også give forskere på deres respektive forskningsinstitutioner adgang til disse. Vi vurderer, at der i fremtiden vil komme flere finansieringsmuligheder gennem danske, nordiske og europæiske institutioner, hvor det er en god ide at være knyttet til nationale og internationale netværk, hvis man vil have del i disse midler.

4. Intern organisering: Vi vurderer, og rapportens resultater tyder på det, at forskningsbibliotekerne vil kunne spille en vigtig rolle inden for citizen science fremover. Det stiller imidlertid krav til deres interne organisering. Eksisterende services skal måske tilbydes til nye målgrupper, mens nye services skal udbydes til nye eller eksisterende målgrupper. Der vil formentlig opstå delte services, som udbydes i samarbejde med andre afdelinger fra samme institution eller gennem helt nye partnerskaber. Citizen science-feltet er karakteriseret ved mange forskellige organiseringsformer, og der er identificeret mange forskellige servicebehov i forhold til konkrete projekter. Derfor anbefales det, at bibliotekerne i stigende grad stræber mod en fleksibel form for organisering, eventuelt arbejder projekt- eller matrix-organiseret.

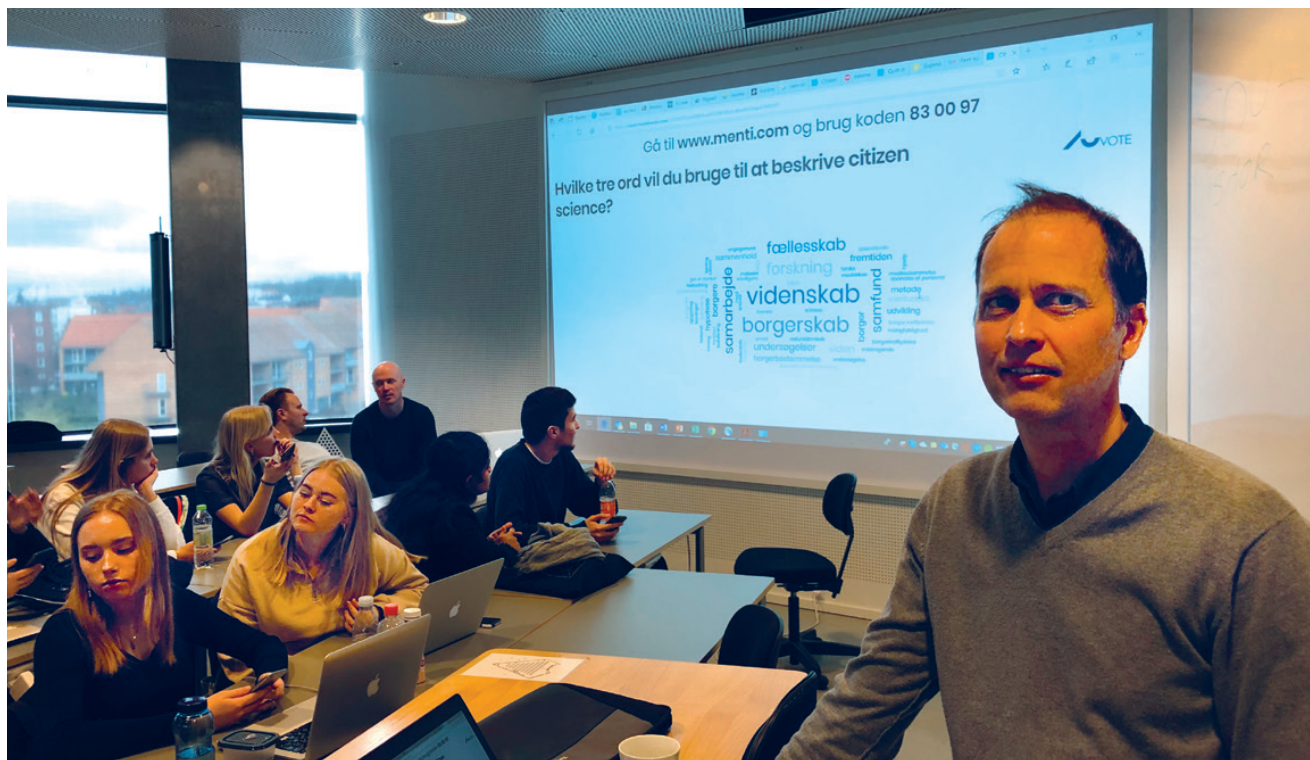

\subsection{Operationelle anbefalinger}

På det operationelle niveau har vi følgende anbefalinger til forskningsbibliotekerne:

5. Advocacy: Et af elementerne i BESPOC-modellen er "advocacy", dvs. videndeling omkring og udbredelse af kendskab til citizen science. Vi vurderer, at der er et øget behov blandt forskere og borgere for mere viden om, hvad citizen science er, hvad man bruger det til, og hvordan man bliver aktiv inden for citizen science-projekter. Her har forskningsbibliotekerne en vigtig rolle at spille, som der også er opmærksomhed på blandt spørgeskemaundersøgelsens respondenter, jf. afsnit 4.2.3. I den forbindelse anbefales det, at forskningsbibliotekerne er opdaterede på nyeste viden om citizen science og i dialog med deres forskningsmiljøer præsenterer og diskuterer begrebet, samt hvordan det kan bruges i forskningen og forskningsformidlingen. Tilsvarende er rekruttering og fastholdelse af frivillige borgere i kommende og eksisterende projekter et afgørende aspekt af citizen science, hvor forskergrupper i nogle tilfælde har brug for partnere som for eksempel forskningsbibliotekerne.
6. Kompetenceudvikling: Et interessant resultat af rapporten er, at hele $85 \%$ af respondenterne mener forskningsbibliotekerne fremover kan spille en rolle inden for citizen science, men at kun $25 \%$ mener, at der er de nødvendige kompetencer til stede. I den forbindelse anbefales det, at forskningsbibliotekerne arbejder målrettet med kompetenceudvikling inden for eksempelvis evidensbaseret viden om citizen science (state of the art), kommunikation om citizen science og afrapportering af citizen science-resultater (se også punkt 7), projektledelse samt brug af citizen science til at fremme "science literacy" og science-didaktik (se også punkt 8).

7. FAIR data og forskningsdata management: Som led i DEFF-projektet "Identificering af fag-og forskningsbibliotekernes rolle ift. udbredelse og understøttelse af Citizen Science" har der været en arbejdsgruppe med særlig fokus på datahåndtering, særligt begreber som FAIR data og forskningsdata management (research data management, RDM). Her har det vist sig, at der er stort potentiale for bidrag til citizen 
science-projekter fra forskningsbibliotekerne. Det anbefales på baggrund heraf, at forskningsbibliotekerne:

a. er med til at sikre adgang til PID'er (ex. DOI), nødvendige datalicenser samt publikation og indeksering i åbne databaser (repositories),

b. indgår i dialog med forskere om FAIR data-principperne (DeiC, 2020) og om udarbejdelse af datamanagement planer for datahåndtering tidligt i projekterne,

c. er med til at sikre, at der i budgettet allokeres midler til god datahåndtering i alle dele af projektet,

d. tydeliggør bibliotekernes eksisterende RDM-kompetencer i forhold til Citizen Science-projekter og udarbejde eller identificere egnede vejledninger for RDM og FAIR data.

e. deltager i internationale sammenhænge (vidensopbygning) omkring FAIR data og RDM i Citizen Science sammenhænge ( $f x$ LIBER).

8. Undervisning inden for citizen science: DEFF-projektet har identificeret et behov for undervisning $i$ citizen science til universitetsstu- derende på alle niveauer. Der har været afprøvet forskellige undervisningsformater med deltagelse af ansatte fra forskningsbibliotekerne.

Dette arbejde anbefaler vi, bør fortsættes. En særlig anbefaling til citizen science-undervisning på ph.d.-niveau vil være at integrere citizen science i fagfaglige kurser eller brede "transferable skills"-kurser om for eksempel ansvarlig forskningspraksis eller samfundsansvarlig forskning og innovation. En række eksisterende citizen science-projekter har løbende samarbejde med folkeskoler og gymnasier, og her kan ansatte fra forskningsbibliotekerne også bidrage. Det kræver nødvendige viden og kompetencer i forhold til:

a. kursus- og modulopbygning på bachelor-og kandidatuddannelser

b. beskrivelse og opfyldelse af læringsmål samt fagbeskrivelser i folke- og gymnasieskolen

c. didaktik og pædagogik i forbindelse med fælles, "samskabte" undervisningsaktiviteter, herunder begreberne science literacy og nature of science (Khine, 2012; OECD, 2017)

\section{CITIZEN SCIENCE I DANMARK}

Projekter, litteratur og aktører

(Aarhus: Center for Videnskabs-

studier, Aarhus Universitet, og

Aarhus Universitetsforlag 2020).

Torben Esbo Agergaard,

Gitte Kragh og

Kristian Hvidtfelt Nielsen.

Udkommet 16. november 2020

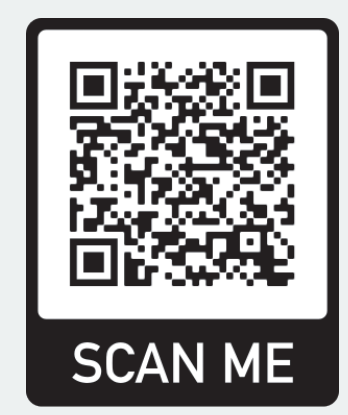

https://unipress.dk/udgivelser/c/ citizen-science-i-danmark/

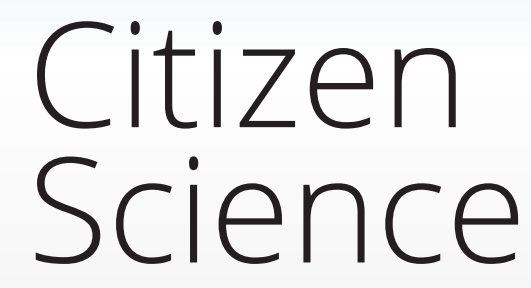

DEFF-projektet har arbejdet med partnerskaber mellem FFU-biblioteker, forskere, studerende og borgere - herunder diverse mediepartnere - for på den måde at identificere FFU-bibliotekernes roller. Dette sker ved at indgå nye samarbejder eller deltage i igangværende Citizen Science-projekter.

Derudover har projektet arbejdet med kompetenceudvikling, videnspredning, undervisning samt biblioteket om Citizen Science 'Hub'. En væsentlig del var at undersøge det danske Citizen Science-landskab samt i forlængelse heraf at identificere og anbefale mulige roller for bibliotekerne.

Deltagere: UCL Bibliotek, UC Syd Bibliotek, DTU Bibliotek,

Det Kongelige Bibliotek, Aalborg Universitetsbibliotek, RUB, SDUB og Aarhus Universitet (Center for Videnskabsstudier). 